\title{
Correlations between types of culture, styles of communication and forms of interreligious dialogue
}

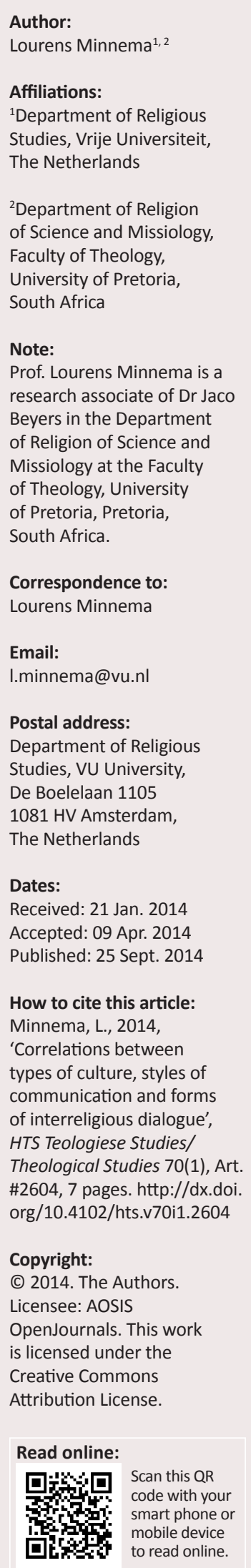

This article argues that culture encodes behavioural and conceptual patterns of dealing with inside-outside boundaries, and that as a consequence, different types of culture are likely to encode different styles of communication and corresponding forms of dialogue. It suggests that dialogical partners may benefit from the insight that interreligious dialogue tends to display patterns related to the underlying mechanisms of intercultural communication and that these cultural mechanisms are more influential in the dialogical process and outcome than the religious ideals pursued. Developmental models of dialogue in particular will be discussed.

\section{Thesis and approach}

The call for interreligious dialogue appeals strongly to those who feel the need to face the appearance of religions on the world scene of intercultural communication, globalised discourse and bomb attacks. Moral indignation and fear, fear of war and instability, as well as fear of threat and disintegration seem sufficient grounds to answer the call and to engage in some kind of interreligious dialogue. Religious leaders often entertain lofty ideals about interreligious dialogue, like establishing world peace, promoting justice, encountering God in the other, sharing religious experiences, bridging gaps, and so on. This idealism may be justified, but in practice interreligious dialogue tends to display patterns related to the underlying mechanisms of intercultural communication. My thesis is that these cultural mechanisms are more influential in the dialogical process and outcome than are the religious ideals. This, at least, will be the starting point of my approach: the understanding of religion as a cultural phenomenon and of interreligious dialogue as a specific case of intercultural communication. My argument is basically that culture encodes behavioural and conceptual patterns of dealing with inside-outside boundaries, and that as a consequence, different types of culture are likely to encode different styles of communication and corresponding forms of dialogue, including models of dialogue.

Developmental models of dialogue, like the ones I will discuss, tend to introduce various degrees of 'openness to difference' and of 'integration of otherness' that are framed within larger goals of dialogue, such as 'learning from others', 'learning to accept others' and 'cooperation with others'. Developmental models of dialogue, then, seem to suggest differences between 'lower' and 'higher' levels in the dialogical process of moving towards these objectives. It is not easy to avoid the impression that some forms of dialogue are less advanced than other ones if measured by the ideal outcome that a particular model of dialogue seems to promote. My own model of three types of culture is also a case in point because it is based on a distinction that has the disadvantage of suggesting a historical development from one level to the next level: the distinction between 'traditional', 'modern', and 'postmodern' types of culture. In order to clarify the potential and limits of my model in dealing with the issue of dialogue as a developmental process towards some goal, in addition to the issue of interreligious dialogue as a specific case of intercultural communication, I would like to include a discussion of two other developmental approaches to dialogue, a cultural one offered by Milton J. Bennett $(1986,1993)$ and a theological one offered by Gort (2008).

\section{First model: Bennett's stages of intercultural sensitivity}

There are two main reasons to discuss Bennett's developmental approach to intercultural communication $(1986,1993)$ within the framework of this article. First of all, as an intercultural approach, Bennett's model is applicable to interreligious dialogue. It suggests one way of demonstrating that cultural mechanisms may be more influential in the dialogical process and outcome than the religious ideals pursued. The model charts six stages of intercultural sensitivity. In order to illustrate its applicability to interreligious dialogue, I added the majority of the examples from religion in the description that follows. Secondly, Bennett's model demonstrates that different developmental models of dialogue have different understandings of what is 
meant by 'development'. Bennett offers a reconstruction of the stages along a continuum that learners report they go through when they experience cultural difference whilst moving from complete ethnocentrism to complete ethnorelativism. His model leaves the impression of moving towards a postmodern goal: the celebration of difference.

In the first stage, which Bennett (1986:182) calls 'denial of difference' even though he means 'absence of perception of difference', physical or social isolation may preclude any contact at all with cultural difference. One's own world view is absolute and unchallenged. Other world views are either not noticed and not perceived as existing or ignored and denied. Religious parochialism would be an example.

In the second stage, 'defense against difference' (Bennett 1986:183), cultural dissimilarity is recognised as real and perceived as a serious threat. Exposure to it elicits negative stereotyping of others, the assumption of one's own cultural superiority including an attitude of condescending tolerance of others, or the reverse, the assumption of the superiority of the host culture and the denigration of one's own way of life. Religious demonising would be an example.

In the third stage, 'minimisation of difference' (Bennett 1986:183), one cherishes an abstract idea of cultural similarity as a last resort to preserve what remains of one's ethnocentrism. By trivialising difference, one tries to 'bury' difference under the weight of cultural similarities. In religion, 'transcendent universalism' would be an example, or, in theological terms, voicing statements such as 'ultimately, we are all children of God' during the course of conversations with atheists, who do not want to be included in that 'we'.

The fourth stage, 'acceptance of difference' (Bennett 1986:184), represents a shift from ethnocentrism to ethnorelativism. Cultural difference is now no longer viewed in terms of deviation but acknowledged and respected as a natural condition of life and intrinsic to human nature. People behave differently and they value things differently. First comes the acceptance of behavioural difference, after which comes the acceptance of underlying value differences. In religion, followers of different religions living together peacefully as neighbours would be an example.

The fifth stage, 'adaptation of difference' (Bennett 1986:185), constitutes the heart of intercultural communication, Bennett contends, because it accepts difference as a relative process and it allows people to change their behaviour and thinking accordingly. The most common form of this adaptation is empathy. Empathy puts someone in the shoes of the other person, at least temporarily and partially. Active religious pluralism, in the sense of the intention and ability to easily shift into two or more religious world views, would be an example.

In the sixth stage, 'integration of difference' (Bennett 1986:186), diversity is embraced as an integral part of one's identity. Here judgements are made and evaluated as to appropriateness contextually, that is, relative to a particular set of cultural conditions and circumstances. Difference is experienced as an essential and joyful aspect of all life. In religion, examples would be attitudes and states of mind radically transformed by the mood of love and wonder, by the taste of beauty and balance, by the touch of forgiveness and reconciliation.

\section{Second model: Gort's theological types of interreligious dialogue}

The second model I would like to highlight seems a purely theological one. Jerald Gort's (2008:758-761) theological approach of a Christian ecumenical theology of religions contains a model of four types of interreligious dialogue. But again, it illustrates that different developmental models of dialogue have different understandings of 'development'. Compared to Bennett's model, Gort's model gives the impression of moving towards a modern (instead of postmodern) goal: cooperation on societal issues in substitution for power struggles and social conflicts. Both Bennett and Gort stress, however, that the stages or levels may occur simultaneously and do not follow a rigidly fixed sequence.

The first level of interreligious dialogue is the 'dialogue of histories' (Gort 2008:759). This dialogue engages in a serious analysis of socio-political and economic relations in the past between the religions of the dialogical partners concerned, and it raises the painful issues of collective (in)justice, power and domination, wealth and poverty, and conflict and hatred due to exploitation and oppression.

The second level of interreligious dialogue is the 'dialogue of theologies' whose purpose is to remove a mutual lack of knowledge and understanding 'of the deepest meaning and intention of one another's religious tenets' (Gort 2008:759) and to 'foster respect and tolerance among people of different faiths'(Gort 2008:758).

The third level, the 'dialogue of spiritualities' (Gort 2008:760) includes mutual interfaith witnessing to the truth as one receives, perceives and experiences it. At this level, 'religious believers would talk together heart to heart about their deepest fears and highest hopes' (Gort 2008:760). Gort suggests that in the Christian ecumenical view, the free and full acceptance of the other becomes possible because it is founded on 'religious faith itself, in the sense of basic trust in God, acceptance of acceptance by God' (Gort 2008:760).

The fourth level is the 'dialogue of Life' (Gort 2008:760). It focuses on 'integrative synergies' amongst the religions themselves but also between these and other players in the field of social concerns (injustice and poverty, human conflict and suffering worldwide), on collaborative actions of renewal and transformation.

Gort's theological model moves from power relations, the psychological impact of collective experiences in the past, 
and the need to recognise the pain stored in collective memory (first level), to the cognitive exchange of personal experiences and intentions in the present despite the past (second level). It then moves on to the emotional exchange of intimate experiences that inspire one's motivation (third level). Finally, this inspired exchange is put into a motivated practice for the restoration of life itself (fourth level). Whereas Bennett's model moves from the completely unknown to the completely known, Gort's model starts out with the all too well-known and painfully remembered as a precondition of the exploration of the much less known and misunderstood. Gort's first level is about recognition instead of minimisation of (traumatising) difference. Gort's second level has the purpose of overcoming stereotypes (Bennett's [1986:183] 'defense strategy') and of entering Bennett's stage of acceptance of difference. This is confirmed by Gort's emphasis on the notion of acceptance on the third level. Gort's fourth level aims at integration (Bennett's sixth stage). Despite their noticeable roots in practical experience, both models retain the idealism that goes with (by definition developmental) learning.

\section{Third model: Three types of culture}

Let me now turn to my own model of three types of culture and styles of communication. It draws from a historical development within the humanities in the 20th century. Especially within cultural anthropology, there has been mounting stress on the distance or even gap between culture and the bearers of culture. Broadly speaking, the development of cultural-anthropological thought in respect of the distance between bearers of culture and their culture can, in my opinion, be subdivided into three phases that reflect the discovery, within cultural anthropology, of three types of culture in the history of civilisations. These three types of culture do not just, I suggest, represent a historical sequence of concepts of culture within 20th century cultural anthropology but also an accumulating sequence of types of culture within the history of civilisations that has resulted in contemporary societies combining these three types of culture in the form of cultural layers within each of these societies (see Table 1-A1).

\section{Type 1: Culture as pre-given constant}

At first, culture is taken as an all-embracing reality, as a self-evident way of life (native customs, habits, rituals and symbols) of a people. ${ }^{1}$ According to this view, the power of cultural patterns is dominant. Cultural patterns are pre-given. Here, participants in a given culture can be little else than bearers, holders, representatives and reproducers of that culture, dutifully oriented towards collective expectations, status and role, ritualists respectful of authority. Culture is characterised by custom and habitual behaviour. Highlighted prototypes of this concept of culture are the 'traditional cultures' of egalitarian, small and simply structured societies.

1.Cf. Boas, Malinowski, Radcliffe-Brown, Mauss, Kroeber, Mead, Benedict and the early Geertz (Eriksen \& Nielsen 2001:39-66).

\section{Type 2: Culture as dominating power and as source of conflict and innovation}

After the Second World War, and particularly subsequent to the late 1960s, culture is seen as a source of conflict and as a revolutionary space for innovative initiatives. ${ }^{2}$ Cultural patterns are experienced as (partially) unbearable and their power subjected to challenge. Culture also has the potential to be subversive. Alternative cultures are considered a space for innovative initiatives. Participants in contested cultures are seen as reproducers but also as producers of culture as well as sub-culture or counter-culture. During this period culture is seen as characterised by productive activity and new, innovative content. Highlighted prototypes of this concept of culture are the so-called high cultures of complex, hierarchical societies and the modern culture of Western society since the Renaissance.

\section{Type 3: Culture as domain of potentiality and choice}

Nowadays, culture is seen as a field of possibilities providing room for freedom of choice and the combination of things. ${ }^{3}$ Cultural patterns are deemed transferable or marketable and their power is considered negotiable. Participants are seen as (re)producers of culture, but even more as consumers of culture who put together a choice of options from within their own culture or from different ones. Here culture is seen as characterised by consumption preferences and individual attitudes (Bourdieu's culture as habitus). The political culture tends to be democratic in the sense of selling the message in a market of individual voters. Highlighted prototypes of this concept of culture are 'multicultural societies', 'mixed cultures' and 'cultures dominated by globalising postmodernism'.

\section{Three styles of communication}

Three different value orientations and styles of communication (see Table 2-A1) correspond respectively to the three types of culture outlined above.

\section{Traditional style of communication}

The traditional holder of culture is faced with role expectations. He is judged by his ability to embody the

2.In 1968, Theodore Roszak publishes The making of a counter culture. Edward Sapir stills sees culture as a common ground but as a common ground for contestation, as stills sees culture as a common ground but as a common ground for contestation, as a basis for disagreement instead of consensus, Max Gluckmann shows an interest in social change and confict but conflict still as ultimately integrating society; likewise, the early Victor Turner sees ritual as mitigating conflict and strengthening socia cohesion; Edmund Leach, like Malinowski, sees myths as sociopolitical charter but as 'charters for trouble', according to Eriksen and Nielsen (2001:66; 86-89) who observe a shift in anthropological focus from integration to process, from continuity to change, from social structure to social organisation, and from (static) status to (dynamic) role in the 1950s and 1960s in Britain and the United States of America, and in Britain a shift from the collective to the individual (Eriksen \& Nielsen 2001:95). In the 1970s, power becomes a focus of Godelier, Wolf, Asad, Mintz, Barth, Giddens, Bourdieu and Foucault (Eriksen \& Nielsen 2001:112-130; Schoenmakers 2012:73-87). Also illustrative of the transition from phase 1 to phase 2 is, in my opinion, the rise of sociology of knowledge. In this approach, culture is viewed as a cumulatively built-up constant, the innovative and conflict-resolvin is viewed as a cumulatively built-up constant, the innovative and conflict-resolving potential of which is managed by the intellectual elite, whereby differentiation is conflicts (cf. Scharfschwerdt 1979:204).

3.For the shift in the 1980s from Modernism to Postmodernism, see Augé (1992); B.For the shift in the 1980s from Modernism to Postmodernism, see Auge (1992);
Brightman (1995:509-546); Habermas (1981:3-14); Keesing (1994:301-312); Brightman (1995:509-546); Habermas (1981:3-14); Keesing (1994:301-312);
Le Rider and Raulet (1987); Lyotard (1979); Maffesoli (1988); Turner (1996:xxx); Vuyk (1992). 
honourable tradition, and that representation is expected to be sufficiently, often monumentally imposing as well as highly ritualised and authoritative. He is held accountable for the degree of his compliance with the normative tradition. His loyalty is measured by his self-evident and willing identification with the tradition he represents. In terms of value orientation and purpose of communication, primary goals are the reproductive transmission of given values and monocultural forms of education in the sense of initiation into one's own tradition.

\section{Modern style of communication}

The modern bearer of culture is faced with the call for critical renewal of tradition and society. As an independent individual, he is determined to contribute to the ideal of general well-being. His sense of (self)disciplined freedom and responsibility is founded on his (self-)conscious and socially engaged self-positioning in the public and private spheres of society. In terms of value orientation and purpose of communication, primary goals are the critical clarification and productive development of existing and new value systems and multicultural forms of education in the secular sense of equal treatment of several traditions simultaneously, including the juxtaposition of their insider perspectives and an examination of their anthropological comparability from an outsider perspective.

\section{Postmodern style of communication}

The postmodern bearer of culture is aware of his personal right, limited only by budgetary considerations, to make his own choices in a complex field of possibilities. As an interdependent networker with many identities, he puts forward his own profile in as seductive a way as possible. He seeks to attractively present and represent himself and his selfdetermined availability for the market on the basis of his own tastes, noncommittal choices, and free offers. In terms of value orientation and purpose, the primary goals and outcomes of this mode of communication are as follows. In valuerelativism, meaning that no single value seems to be accepted as normative and taken for granted, every value system seems to be problematised and debated publicly before an audience of consumers who express their likes and dislikes, except for presupposed values such as the individual right to choose, to exchange, to be authentic and to be autonomous. Creative communication of values refers to an interactive attunement to the wide range of values on offer with a view to pleasing clients, serving image-building, and promoting an attitude of mutual understanding and respect. This includes one-and-all participation in the process of communication. Intercultural forms of education looks at helping individuals improve their own skills through the agency of dialogical exchange of perspectives and existential exposure to other life styles.

\section{Three forms of interreligious dialogue}

Applied to religion, the subject matter discussed above yields the following outcomes in respect of religious self- understanding attitudes of religions towards other faith traditions, and interreligious dialogue.

\section{Traditional culture and interreligious dialogue}

In the case of traditional culture, religion is first of all taken to be the self-evident way of life and its truth to be single and unambiguous: 'All Africans are religious by nature. It is in their genes'. Religion is upheld as the norm and ideal to be publicly applauded and stood with in solidarity: 'Our religion stands for everything that is good and beautiful' and 'If everybody would abide by their religion, the world would be a better place'. Or as expressed by Mohammed Ali after 9/11: 'They hijacked my religion which is one of peace and justice'. The message is role-oriented rather than person- or content-oriented. Many West African church communities, across the theological spectrum, invest huge sums of money in having bigger church buildings and bigger cars for the pastors representing their communities, instead of investing their money in relieving the poverty of their fellow church members who are considered much less representative, let alone relieving the poverty of outsiders.

Secondly, in traditional cultures, outsiders are seen as strangers, unknown and/or unloved. They may be treated as guests honoured according to their status but are nevertheless put in quarantine. Role confusion and insult occur when outsiders seem to behave as if they were insiders: 'How can you teach (reproduce) religion without being religious?' 'How is it possible to have taught our religion for so many years without being converted to it?' Outsiders are not allowed to criticise insiders. If an outsider responds to the statement, 'Our religion stands for everything that is good and beautiful', by asking 'Surely, you do not believe that seriously yourself, do you?', the orientation of his message shifts from role to person and content, thus shaming instead of honouring his interlocutor. Criticism of traditional religion is taboo for outsiders. Insiders are allowed self-criticism of the tradition provided it addresses the in-group only: 'Not every believer lives up to our beloved religion'. Outsiders should not publicly repeat or explicitly quote this selfcriticism, but rather take up the implicit desire for change it entails. Instead of saying, 'So you agree with me that many believers fail to live up to their religion?', which comes down to an effort to turn the insider into an ally of the outsider, the response should take the form of a supportive question: 'Do you wish more of your fellow believers would better live up to your religion?'

Thirdly, the types of interreligious dialogue appropriate here are a 'dialogue of ritual hospitality', paying formal and informal visits to each other, and a 'dialogue of religious narratives', in the sense of an informative colloquy held, for purposes of explaining the meaning of ritual practices and religious stories, by participants conscious of their traditions as something precious and worthy of reproduction. Misunderstanding may occur when a clearly shared topic turns out to be much more central to one's own religious system than to the religious system of the conversation 
partners. These types of dialogue are exploratory in nature. Their purpose is the creation of an atmosphere in which the participants can get to know and come to respect each other; and they have as additional important goals preventive reduction of participant insecurity, polite reciprocal affirmation of status, and mutual display of hospitality.

\section{Modern culture and interreligious dialogue}

In modern culture, religion is first of all perceived as a source of conflict bearing the character of a power struggle for control of image-building and meaning-making. Religion's symbolic potential is considered to be strategically mobilised for socio-political purposes. Religions use symbolic and conceptual language to communicate, and interest groups make use of this language too. Religious image-building is also a sensitive issue in interreligious dialogue, because of the fact that adherents of one religion frequently fall prey to stereotypical, hackneyed observations about other religious traditions: 'Buddhism is egocentric', 'Islam is fundamentalist', 'Christianity advocates dialogue', and 'Christians are crusaders'. Often, there is a tendency to play off the inspiring ideals of a given religion against the disappointing realities of other religions, or in the case of self-criticism, against the below par actualities of one's own religion.

Secondly, outsiders are accounted for as potential critics whose cognitive arguments should be welcomed and listened to. External critics, or rather their criticism, can also be mobilised strategically against internal opponents. Their expected role is to provide critical content in a rational debate. The existence of religious outsiders is taken into account conceptually in subdisciplines such as 'theology of religions' or in legal rules for religious minorities. The Salman Rushdie affair, for example, is perceived as a culture clash between 'traditional' and 'modern' value orientations, or, put differently, as a power struggle involving the question of whether Muslims alone or also critical outsiders who claim freedom of expression have the authority and are warranted to determine the public image of Islam (Beyer 1994:1-10).

Thirdly, there are three types of interreligious conversations appropriate to modern culture and its style of communication:

- a dialogue of histories, wherein the participants mutually share their historical and contemporary perceptions of the other, their self-perceptions and their stories relating to past and present

- a dialogue of doctrines that tries to clarify theological concepts on a cognitive level

- a dialogue dedicated to the promotion of shared aspirations.

In prolonged conflicts, parties on both sides - be they Jews and Arabs, Hutus and Tutsis, Irish Protestants and Catholics are often eager to tell the story of their anxieties and suffering but are rarely ready to listen to the story of their opposite number. Equally challenging to this matter of unwillingness to listen is the problem of establishing a balance of power between the dialogical partners if the religious group to which some of the participants adhere belongs to a different socioeconomic class than that of the other participants. Scanning the social status of one's conversation partner is one of the first mechanisms that human communication triggers, according to Vink (2005:31-60). The purpose of these types of dialogue is to provide room and conditions for the removal of prejudices and misconceptions, and for the facilitation of mutual recognition, peaceful coexistence and cooperation, proactive confidence building, collaborative promotion of social justice, religious freedom of expression, constructive mutual criticism and reciprocal learning.

\section{Postmodern culture and interreligious dialogue}

Postmodern culture perceives religion first and foremost as a field of possibilities for choice and combination, as a model on offer and a source of inspiration. Typical is the inclination of individuals to show serious interest in specific forms of religion for a short period of time without long-term engagement. Another tendency is the replacement of the religion of one's early socialisation with the religion of one's own choice. Both tendencies are considered to be expressions of personal freedom and authenticity, and dialogical partners are taken seriously for their authenticity, not for representing or criticising their religion.

Further, outsiders are no longer considered guests, opponents or allies, because the borders between religions are crossed regularly and every individual is expected to be both an insider and an outsider to the religion of his choice. Here it is crucial not to identify conversation partners with the religion of the group to which they belong but to ask the persons themselves to indicate the extent to which they identify with their religion and with their religious community. For example, the question, 'Your name is Sulayman, isn't it; so you as a Muslim, what do you think about your leaders?', would be considered wrong because the person to whom it is addressed might in fact be a critical or former Muslim who is as allergic to leaders as the inquirer is.

Accordingly, the type of interreligious dialogue appropriate here is a dialogue of spiritualities, an experiential sharing by decentred subjects of journeys of the soul and of personal aspirations and individual coping strategies, an exercise in reflection on the relative but enriching value of the input of the dialogical partners involved. Crucial to exchanges of this nature is the capacity to communicate personal insights and feelings. The characteristic purpose and aim of this type of dialogue is the attainment of mutual existential recognition among the participants, the fostering of their spiritual growth, and the back-and-forth communication of personal insecurity and questions rather than the sharing of certainties and answers.

\section{Conclusion}

The third model enables participants to trace the degree to which misunderstanding in interreligious dialogue may be due to a clash between traditional, modern and postmodern cultures, not just between or among conversation partners from different societies but also between those from one and the same society and those belonging to one and the 
same religion. Modern intellectuals from different traditions may get along much better amongst each other than with traditional authorities within their own tradition. It is possible that postmodern conversation partners may aggravate and even anger traditional and modern believers for relativising any and all commitments except those entailing pursuit of one's spiritual quest.

The discussion above illustrates that, in practice, developmental models need not be applied rigidly in order to be useful. Employment of the conceptual construct of sequential historical development from 'traditional' to 'modern' to 'postmodern' is meant to provide clarification, but it can also be misleading. First of all, the purposes of interreligious dialogue do not coincide with the progression towards postmodernism, as if this were the highest stage of developmental learning. Secondly, contemporary cultures have not replaced previous cultures by erasing them but, on the contrary, consist of a combination of traditional, modern and postmodern cultural patterns, a sequence of layer upon layer. These cultural patterns do not come down to the same thing and do not disappear. The impact of their layered presence remains noticeable. Participants in interreligious dialogue may benefit from being able to distinguish between them.

\section{Acknowledgements}

\section{Competing interests}

The author declares that he has no financial or personal relationship(s) that may have inappropriately influenced him in writing this article.

\section{References}

Augé, M., 1992, Non-lieux: Introduction à uneanthropologie de la surmodernité, Editions du Seuil, Paris.

Bennett, M.J., 1986, 'A developmental approach to training for intercultura sensitivity', International Journal of Intercultural Relations 10, 179-196. http:// dx.doi.org/10.1016/0147-1767(86)90005-2

Bennett, M.J., 1993, 'Towards ethnorelativism: A developmental model of intercultura sensitivity', in R. Michael Paige (ed.), Education for the intercultural experience, pp. 10-51, Intercultural Press, Yannouth.

Beyer, P., 1994, 'Introduction: Religion in global society', in P. Beyer (ed.), Religion and globalization, pp. 1-10, Sage Publications, London.

Brightman, R., 1995, 'Forget culture: Replacement, transcendence, relexification', Cultural Anthropology 10(4), 509-546. http://dx.doi.org/10.1525/can. 1995.10.4.02a00030

Eriksen, T.H. \& Nielsen, F.S., 2001, A history of anthropology, Pluto Press, Virginia/ Sterling, London.

Gort, J.D., 2008, 'The search for interreligious convivance, ongoing challenge and charge', Verbum et Ecclesia 29(3), 744-763. http://dx.doi.org/10.4102/ ve.v29i3.30

Habermas, J., 1981, 'Modernity versus postmodernity', New German Critique 22, 3-14. http://dx.doi.org/10.2307/487859

Keesing, R.M., 1994, 'Theories of culture revisited', in R. Borofsky (ed.), Assessing Cultural Anthropology, pp. 301-312, McGraw-Hill, New York.

Le Rider, J. \& Raulet, G. (eds.), 1987, Verabschiedung der (post-)moderne? Eine interdisziplinäre debatte, Günter Narr, Tübingen.

Lyotard, J.-F., 1979, La condition moderne: Rapport sur le savoir, Les Editions de Minuit, Paris.

Maffesoli, M., 1988, Le temps des tribus: Le déclin de l'individualisme dans les sociétés de masse, Meridien Klincksieck, Paris.

Scharfschwerdt, J., 1979, 'Arnold Hauser (1892-1978)', in A. Silbermann (ed.), Klassiker der kunstsoziologie, n.p., Beck, München.

Schoenmakers, H., 2012, The power of culture: A short history of anthropological theory about culture and power, University of Groningen, Groningen.

Turner, B.S., 1996, For Weber: Essays on the sociology of fate, Sage Publications, London.

Vink, N., 2005, Dealing with differences, KIT Publishers, Amsterdam.

Vuyk, K., 1992, De esthetisering van het wereldbeeld: Essays over filosofie en kunst, Kok Agora, Kampen. 


\section{Appendix 1}

TABLE 1-A1: Culture types.

\begin{tabular}{|c|c|c|}
\hline Traditional culture & Modern culture & Postmodern culture \\
\hline The power of cultural patterns is considered: & The power of cultural patterns is considered: & The power of cultural patterns is considered: \\
\hline $\begin{array}{l}\text { 1. integral, all-encompassing } \\
\text { 2. self-evident } \\
\text { 3. dominant } \\
\text { 4. located in the timeless elite of the upper classes }\end{array}$ & $\begin{array}{l}\text { 1. differentiated per sector } \\
\text { 2. functional } \\
\text { 3. contested, a conflict between dominant culture, } \\
\text { counter cultures and subcultures } \\
\text { 4. located in individuals who organise themselves in } \\
\text { interest groups and economic classes (later also } \\
\text { nations) }\end{array}$ & $\begin{array}{l}\text { 1. fragmentary, hybrid } \\
\text { 2. transferable } \\
\text { 3. negotiable } \\
\text { 4. located in mass movements and virtual collectivities } \\
\text { that can be mobilised temporarily }\end{array}$ \\
\hline \multicolumn{3}{|l|}{ Culture is characterised as: } \\
\hline $\begin{array}{l}\text { 5. pregiven and constant } \\
\text { 6. confirming existing expectations } \\
\text { 7. reproductive } \\
\text { 8. ritual en elevated } \\
\text { 9. respecting authority and dutiful } \\
\text { 10. status oriented and role oriented } \\
\text { 11. family oriented and group focused } \\
\text { 12. conservative } \\
\text { 13. focussed on representation, idealising, monumentally } \\
\text { imposing } \\
\text { 14. memorizing information cumulatively } \\
\text { 15. categorising and hierarchising } \\
\text { 16. protective of boundaries } \\
\text { 17. stressing individuality of groups }\end{array}$ & $\begin{array}{l}\text { 5. makeable and changeable } \\
\text { 6. bound to progress } \\
\text { 7. productive } \\
\text { 8. rational and civilized } \\
\text { 9. business-like and along legal rules } \\
\text { 10. focussed on interests, conflicts, coalitions and } \\
\text { contracts } \\
\text { 11. individual as basic unit and state oriented (later also } \\
\text { nation oriented) } \\
\text { 12. renewing, revolutionary } \\
\text { 13. designing, self-disciplining, focused on control and } \\
\text { planning } \\
\text { 14. analysing specialised information } \\
\text { 15. standardising and equalising } \\
\text { 16. regulating boundaries } \\
\text { 17. ignoring diversity of individuals and groups }\end{array}$ & $\begin{array}{l}\text { 5. possibility and as variable } \\
\text { 6. fit for combination and sale } \\
\text { 7. consumptive } \\
\text { 8. emotional and based on need } \\
\text { 9. focussed on choice and conscious of taste } \\
\text { 10. directed to trends and situations } \\
\text { 11. mass oriented and network oriented } \\
\text { 12. experimental, improvising } \\
\text { 13. aestheticizing, seductively marketing, connecting } \\
\text { 14. eclectically accessing information } \\
\text { 15. flexible, switching } \\
\text { 16. crossing boundaries } \\
\text { 17. accepting individual diversity }\end{array}$ \\
\hline
\end{tabular}

(c) 'Culture types' Lourens Minnema

TABLE 2-A1: Styles of communication.

Traditional bearer of culture, style of communication, value orientation

1. Monumentally imposing representation

2. Obedience

3. Self-evident and willing identification with the tradition

4. Transmission of values

5. Monocultural education

(C) 'Styles of communication' Lourens Minnema
Modern bearer of culture, style of communication, value Postmodern bearer of culture, style of communication, orientation value orientation

1. Self-disciplined freedom 1 . Seductively marketing oneself

2. Responsibility

2. Availability

3. Self-determined and noncommittal market preferences

4. Value relativism and Communication of values

5. Intercultural education 